\title{
Crystal Structure of $\mathrm{ZnCl}_{3}$ (Methyl-(2-Pyridin-2-yl-Ethyl)-Ammonium)
}

\author{
Mahjouba Ben Nasr'1, Erwann Jeanneau², Chérif Ben Nasr ${ }^{1}$ \\ ${ }^{1}$ Université de Carthage, Laboratoire de Chimie des Matériaux, Faculté des Sciences de Bizerte, Zarzouna, \\ Tunisie \\ ${ }^{2}$ Centre Diffractométrie Henri Longchambon, Université Claude Bernard Lyon 1, Villeurbanne, France \\ Email: cherif.bennasr@fsb.rnu.tn
}

Received 24 December 2014; accepted 25 January 2015; published 29 January 2015

Copyright @ 2015 by authors and Scientific Research Publishing Inc.

This work is licensed under the Creative Commons Attribution International License (CC BY).

http://creativecommons.org/licenses/by/4.0/

(c) (7) Open Access

\begin{abstract}
A new Zn(II) complex with the monodentate ligand methyl-(2-pyridin-2-yl-ethyl)-ammonium, $\mathrm{ZnCl}_{3} \mathrm{C}_{8} \mathrm{H}_{13} \mathrm{~N}_{2}$, has been prepared and characterized by single crystal X-ray diffraction. The $\mathrm{Zn}$ (II) ion is tetracoordinated by one nitrogen atom of organic ligand and three chlorine ligands. In the atomic arrangement, the $\mathrm{ZnNCl}_{3}$ tetrahedra form corrugated chains extending along the $b$-axis. The organic entities are located between these chains through $\mathrm{N}-\mathrm{H} \cdot \cdots \mathrm{Cl}, \mathrm{C}-\mathrm{H} \cdots \mathrm{Cl}$ and $\mathrm{C}-\mathrm{H} \cdot \cdots \mathrm{N}$ hydrogen bonds to form layers parallel to $(b, c)$ plan. Among these hydrogen bonds two are bifurcated.
\end{abstract}

\section{Keywords}

\section{X-Ray Diffraction, Coordination Compound, Zinc Complex}

\section{Introduction}

Inorganic-organic hybrid compounds provide a class of materials displaying interesting technological importance [1]. The abilities to combine the properties of organic and inorganic compounds within one single molecular scale leads to interesting crystal structures [2]. In these materials, the crystal packing is ensured by hydrogen bonds and $\pi-\pi$ stacking interactions. These non-covalent weak forces play a vital role in molecular recognition, self organization of molecule and highly efficient and specific biological reactions associated with supramolecular chemistry [3]. In this area, transition metal complexes are known to be effective against rheumatoid arthritis and they also show anti-ulcer activity [4] [5]. These complexes have different molecular geometries, such as tetrahedral, square planar, square pyramidal, trigonal bipyramidal and octahedral [6].

As part of our continued involvement in the investigation of metal complexes of nitrogen containing ligands such as, e.g. Schiff bases [7], we report here the synthesis and characterization of two new Zn(II) complex with the monodentate ligand methyl-(2-pyridin-2-yl-ethyl)-ammonium. 


\section{Experimental}

\subsection{Chemical Preparation}

A solution of $\mathrm{ZnCl}_{2}(0.123 \mathrm{~g}, 0.90 \mathrm{mmol})$ in water was added dropwise to a solution of 2-(2-methylaminoethyl) pyridine $(0.040 \mathrm{~g}, 0.30 \mathrm{mmol})$ in ethanol $(6 \mathrm{~mL})$. After stirring during $30 \mathrm{~min}$, the mixture was filtered. Crystals suitable for X-ray analysis were obtained after four days by slow evaporation of the filtrate at room temperature (yield $=58 \%$ ).

\subsection{X-Ray Single Crystal Structural Analysis}

A single crystal was used for X-ray measurements on Nonius Kappa CCD diffractometer operating at $296 \mathrm{~K}$ with the wavelength $\mathrm{K} \alpha(\mathrm{Mo})=0.7107 \AA$. The structure was solved by direct methods using the SHELXS 86 program [8] and refined by full matrix least-squares techniques using CRYSTALS [9]. All non-hydrogen atoms were refined anisotropically. The drawing were made with Diamond [10] ans Mercury [11]. The details od data collection, refinment and crystallogapfic data are summerized in Table 1.

\section{Results and Discussion}

Single crystal X-ray diffraction analysis reveals that the structure of the title compound is characterized by an isolated structure, based on the protonated 2-(2-methylaminoethyl)pyridine, methyl-(2-pyridin-2-yl-ethyl)-ammonium, ligand coordinating to a zinc atom that is further terminally bonded by three chlorine atoms as in Figure 1. The methylenic group adjacent to the aliphatic nitrogen atom forms a weak intramolecular C-H...Cl hydrogen bond with the Cl1 hydrogen atom. This compound is a so called "zwitterions", where the positive charge is localized at the protonated aliphatic nitrogen atom of the methyl-(2-pyridin-2-yl-ethyl)-ammonium moiety and the negative charge in the vicinity of three chlorine atoms. All the crystallographically independent atoms are in general positions. The $\mathrm{Zn}$ atom has a slightly distorted tetrahedronal geometry, coordinationg with the aromtic nitrogen atom of the cationic ligand and three terminal chlorine atoms (Figure 2). The $\mathrm{Zn}-\mathrm{Cl}$ distances range from 2.2338(10) to 2.2828(8) $\AA$ and the $\mathrm{Zn}-\mathrm{N}$ of 2.0690(18) $\AA$ (Table 2), which are comparable to those reported [12]-[15]. The bond angles of Cl-Zn-Cl and N-Zn-Cl range from 104.60 (3) to 117.74 (3), which are close to those in a regular tetrahedron, agree with that previously described [16]. In the atomic arragment, the $\mathrm{ZnNCl}_{3}$ tetrahedra form corrugated chains extending along the $b$-axis (Figure 3$)$. These chains are located at $(1 / 2,0,1 / 4)$ and $(1 / 2,0$, 3/4) (Figure 4). The organic entities are inserted between these chains through $\mathrm{N}-\mathrm{H} . . . \mathrm{Cl}, \mathrm{C}-\mathrm{H} . . . \mathrm{Cl}$ and $\mathrm{C}-\mathrm{H} . . . \mathrm{N}$ hydrogen bonds to form layers parallel to (b, c) plan (Figure 5, Table 3). These layers are situated at $x=n / 2$ (Figure 6). A perspective view of the whole atomic arrangment is given in Figure 7. It should be pointed out that between the hydrogen bonds two are bifurcated $\mathrm{N} 2-\mathrm{H} 2 \mathrm{~A} \cdots\left(\mathrm{Cl}^{\mathrm{i}}, \mathrm{Cl} 2^{\mathrm{i}}\right)$ and $\mathrm{N} 2-\mathrm{H} 2 \mathrm{~B} \cdots\left(\mathrm{Cl}^{\mathrm{ii}}, \mathrm{Cl}^{\mathrm{ii}}\right)$ (for symmetry codes, see Table 3).

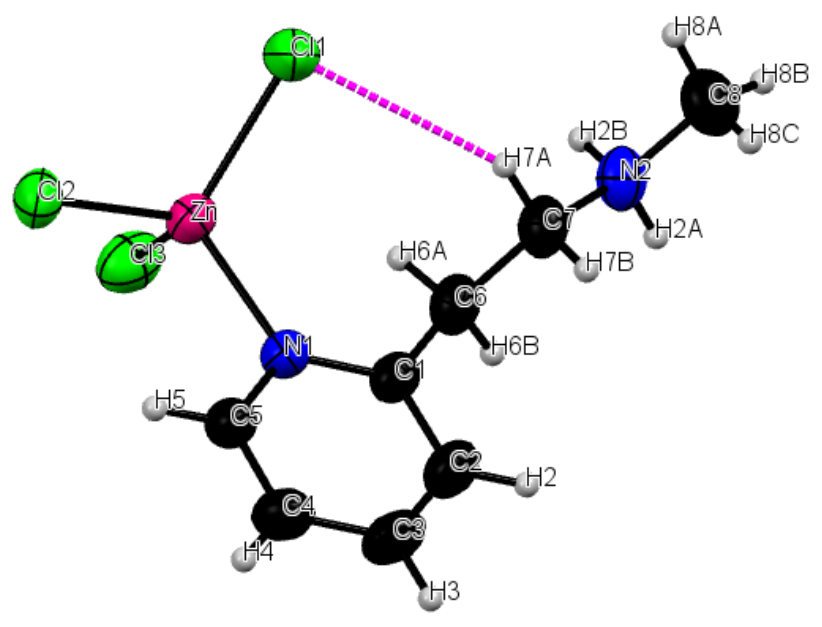

Figure 1. Asymmetric unit of $\mathrm{ZnCl}_{3} \mathrm{C}_{8} \mathrm{H}_{13} \mathrm{~N}_{2}$ with the atom numbering scheme and thermal ellipsoids at $50 \%$ probability. The dotted lines indicate hydrogen bond. 


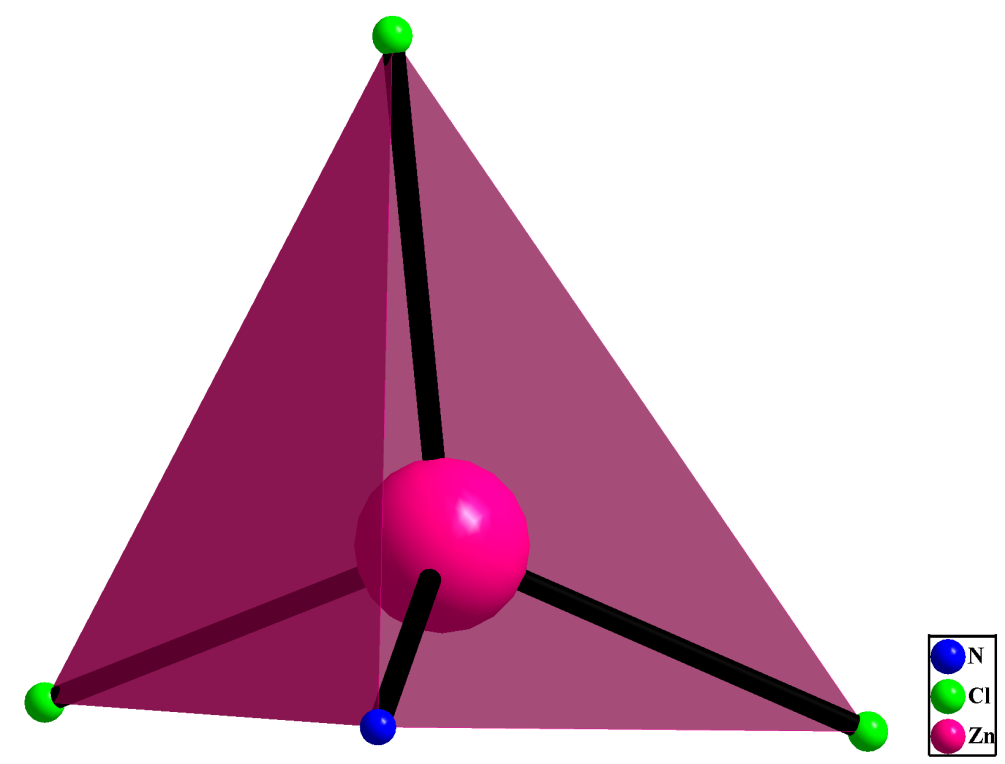

Figure 2. Geometry around the $\mathrm{Zn}(\mathrm{II})$ cation in $\mathrm{ZnCl}_{3} \mathrm{C}_{8} \mathrm{H}_{13} \mathrm{~N}_{2}$.<smiles>CC(C)(C)C</smiles><smiles>CC(C)(C)C</smiles><smiles>CC(C)(C)C</smiles><smiles>CC(C)(C)C</smiles><smiles>CC(C)(C)C</smiles><smiles>CC(C)(C)C</smiles>

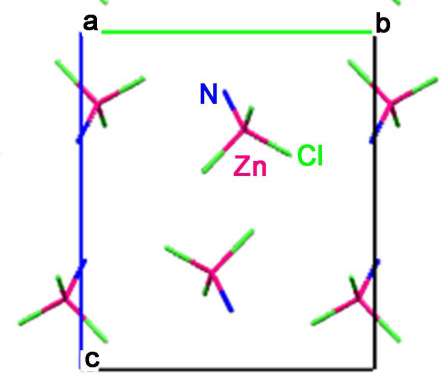<smiles>CC(C)(C)C(C)(C)C</smiles><smiles>CC(C)(C)C</smiles><smiles>CC(C)(C)C</smiles><smiles>CC(C)(C)C</smiles><smiles>CC(C)(C)C</smiles><smiles>CC(C)(C)C</smiles>

Figure 3. Inorganic corrugated chains of $\mathrm{ZnCl}_{3} \mathrm{~N}$ tertrahedra in the title compound. Organic radicals are omitted for figure clarity.

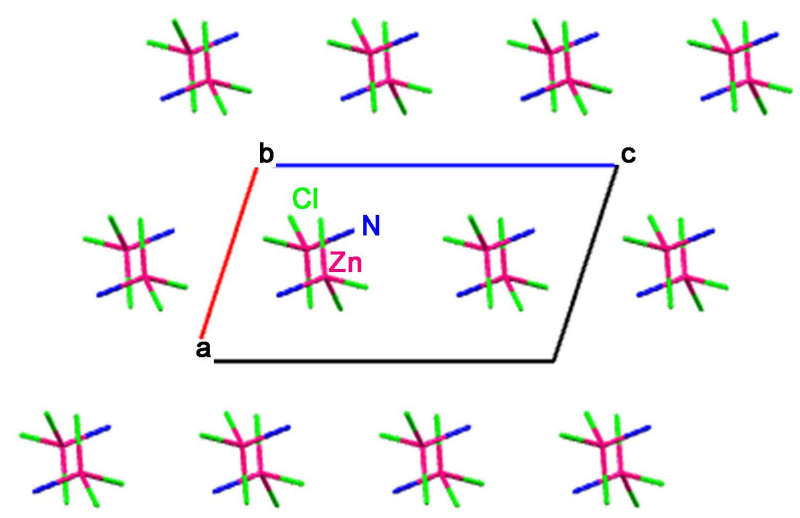

Figure 4. Projection along the $b$-axis of the inorganic chains. Organic radicals are omitted for figure clarity. 


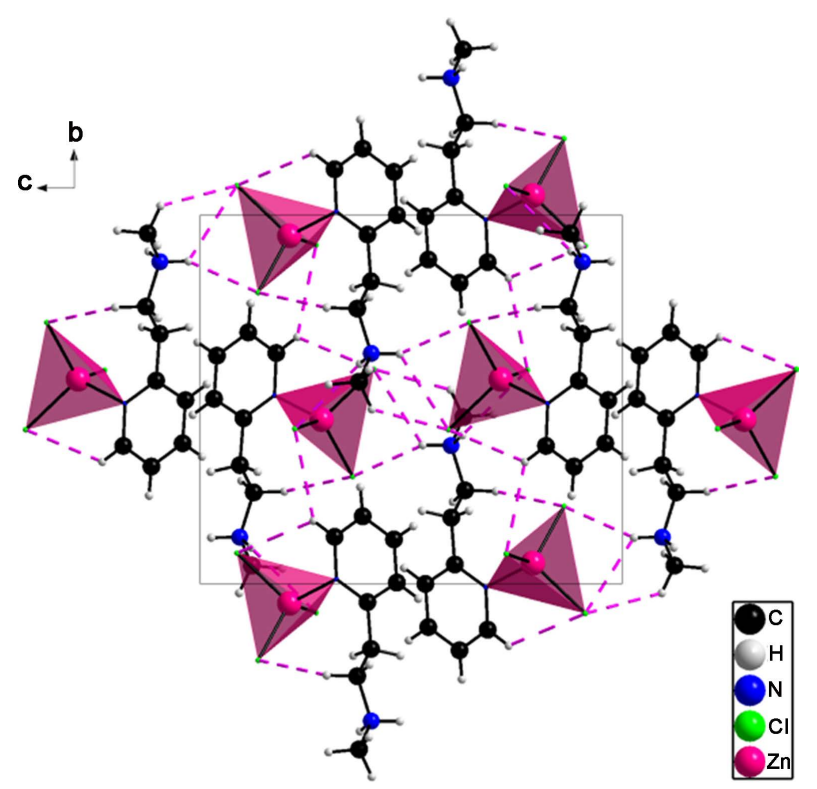

Figure 5. Inorganic-organic layer in $\mathrm{ZnCl}_{3} \mathrm{C}_{8} \mathrm{H}_{13} \mathrm{~N}_{2}$. The dotted lines indicate hydrogen bonds.

Table 1. Experimental details.

\begin{tabular}{|c|c|}
\hline \multicolumn{2}{|c|}{ Crystal data } \\
\hline Chemical formula & $\mathrm{C}_{8} \mathrm{H}_{13} \mathrm{Cl}_{3} \mathrm{~N}_{2} \mathrm{Zn}$ \\
\hline$M_{\mathrm{r}}$ & 308.92 \\
\hline Crystal system, space group & Monoclinic, $P 2_{1} / c$ \\
\hline Temperature (K) & 296 \\
\hline$a, b, c(\AA)$ & 8.020 (3), 11.529 (4), 13.973 (4) \\
\hline$\beta\left(^{\circ}\right)$ & $108.015(2)$ \\
\hline$V\left(\AA^{3}\right)$ & $1228.6(7)$ \\
\hline Z & 4 \\
\hline Radiation type & Mo $K \alpha$ \\
\hline$\mu\left(\mathrm{mm}^{-1}\right)$ & 2.62 \\
\hline Crystal size (mm) & $0.17 \times 0.11 \times 0.09$ \\
\hline \multicolumn{2}{|c|}{ Data collection } \\
\hline Diffractometer & Nonius Kappa CCD diffractometer \\
\hline No. of measured, independent and observed $[I>2 \sigma(I)]$ reflections & 8636, 2912, 2308 \\
\hline$R_{\text {int }}$ & 0.038 \\
\hline$(\sin \theta / \lambda)_{\max }\left(\AA^{-1}\right)$ & 0.657 \\
\hline \multicolumn{2}{|c|}{ Refinement } \\
\hline$R\left[F^{2}>2 \sigma\left(F^{2}\right)\right], w R\left(F^{2}\right), S$ & $0.032,0.090,1.06$ \\
\hline No. of reflections & 2912 \\
\hline No. of parameters & 131 \\
\hline H-atom treatment & H-atom parameters constrained \\
\hline$\Delta \rho_{\max }, \Delta \rho_{\min }\left(\mathrm{e} \AA^{-3}\right)$ & $0.46,-0.50$ \\
\hline
\end{tabular}




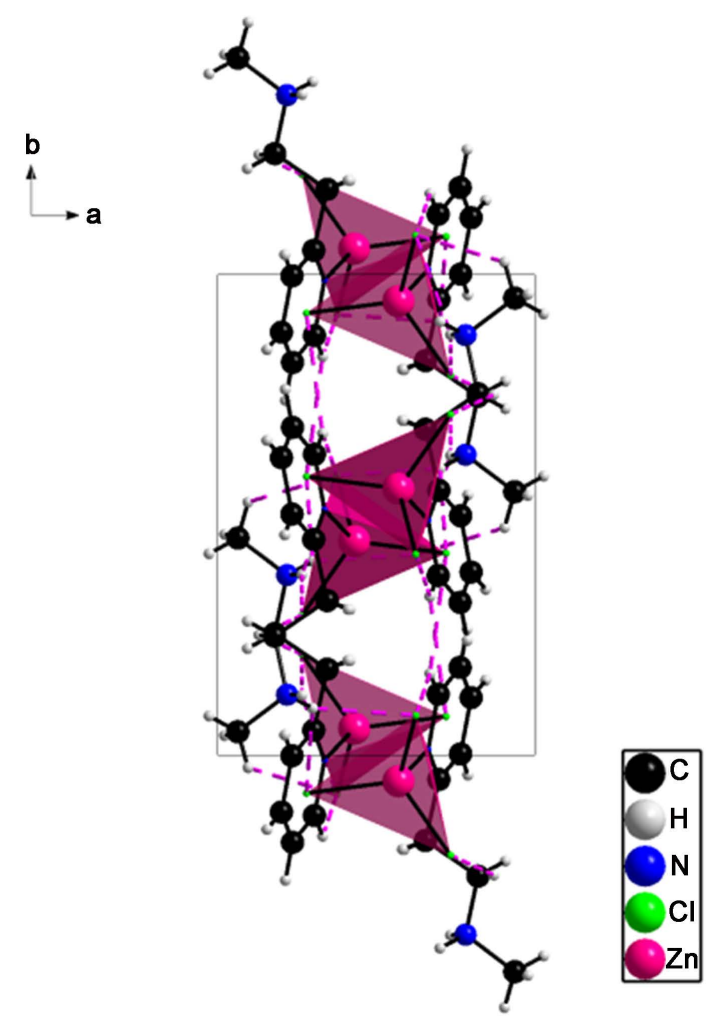

Figure 6. Projection of a layer along the $c$-axis in $\mathrm{ZnCl}_{3} \mathrm{C}_{8} \mathrm{H}_{13} \mathrm{~N}_{2}$. The dotted lines indicate hydrogen bonds.

Table 2. Selected geometric parameters $\left(\AA,{ }^{\circ}\right)$.

\begin{tabular}{|c|c|c|c|}
\hline $\mathrm{Zn}-\mathrm{N} 1$ & $2.0690(18)$ & $\mathrm{N} 2-\mathrm{C} 7$ & $1.483(3)$ \\
\hline $\mathrm{Zn}-\mathrm{Cl} 3$ & $2.2338(10)$ & $\mathrm{C} 1-\mathrm{C} 2$ & $1.394(3)$ \\
\hline $\mathrm{Zn}-\mathrm{Cl} 1$ & 2.2649 (8) & $\mathrm{C} 1-\mathrm{C} 6$ & $1.503(3)$ \\
\hline $\mathrm{Zn}-\mathrm{Cl} 2$ & $2.2828(8)$ & $\mathrm{C} 2-\mathrm{C} 3$ & $1.378(4)$ \\
\hline $\mathrm{N} 1-\mathrm{C} 1$ & $1.348(3)$ & $\mathrm{C} 3-\mathrm{C} 4$ & $1.359(4)$ \\
\hline N1-C5 & 1.349 (3) & $\mathrm{C} 4-\mathrm{C} 5$ & $1.381(3)$ \\
\hline N2-C8 & 1.477 (3) & $\mathrm{C} 6-\mathrm{C} 7$ & $1.524(3)$ \\
\hline $\mathrm{N} 1-\mathrm{Zn}-\mathrm{Cl} 3$ & $109.05(5)$ & $\mathrm{N} 1-\mathrm{C} 1-\mathrm{C} 2$ & $120.8(2)$ \\
\hline $\mathrm{N} 1-\mathrm{Zn}-\mathrm{Cl} 1$ & 109.52 (5) & $\mathrm{N} 1-\mathrm{C} 1-\mathrm{C} 6$ & 119.07 (19) \\
\hline $\mathrm{Cl} 3-\mathrm{Zn}-\mathrm{Cl} 1$ & $117.74(3)$ & $\mathrm{C} 2-\mathrm{C} 1-\mathrm{C} 6$ & $120.1(2)$ \\
\hline $\mathrm{N} 1-\mathrm{Zn}-\mathrm{Cl} 2$ & 106.57 (6) & $\mathrm{C} 3-\mathrm{C} 2-\mathrm{C} 1$ & $119.4(2)$ \\
\hline $\mathrm{Cl} 3-\mathrm{Zn}-\mathrm{Cl} 2$ & $108.75(3)$ & $\mathrm{C} 4-\mathrm{C} 3-\mathrm{C} 2$ & $119.8(2)$ \\
\hline $\mathrm{Cl} 1-\mathrm{Zn}-\mathrm{Cl} 2$ & $104.60(3)$ & $\mathrm{C} 3-\mathrm{C} 4-\mathrm{C} 5$ & $118.7(2)$ \\
\hline $\mathrm{C} 1-\mathrm{N} 1-\mathrm{C} 5$ & $118.59(18)$ & $\mathrm{N} 1-\mathrm{C} 5-\mathrm{C} 4$ & $122.6(2)$ \\
\hline $\mathrm{C} 1-\mathrm{N} 1-\mathrm{Zn}$ & $125.59(14)$ & $\mathrm{C} 1-\mathrm{C} 6-\mathrm{C} 7$ & 111.80 (18) \\
\hline $\mathrm{C} 5-\mathrm{N} 1-\mathrm{Zn}$ & $115.81(14)$ & $\mathrm{N} 2-\mathrm{C} 7-\mathrm{C} 6$ & 111.08 (17) \\
\hline $\mathrm{C} 8-\mathrm{N} 2-\mathrm{C} 7$ & 114.07 (18) & & \\
\hline
\end{tabular}




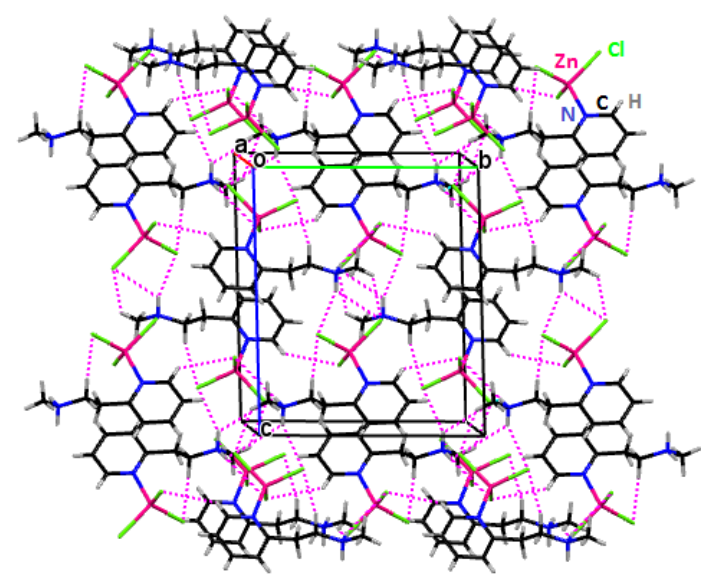

Figure 7. A perspective view of the structure of $\mathrm{ZnCl}_{3} \mathrm{C}_{8} \mathrm{H}_{13} \mathrm{~N}_{2}$. The dotted lines indicate hydrogen bonds.

Table 3. Hydrogen-bond geometry $\left(\AA,^{\circ}\right)$.

\begin{tabular}{|c|c|c|c|c|}
\hline$D-\mathrm{H}^{\cdots} \cdots A$ & $D-\mathrm{H}$ & $\mathrm{H} \cdots A$ & $D \cdots A$ & $D-\mathrm{H} \cdots A$ \\
\hline $\mathrm{N} 2-\mathrm{H} 2 A \cdots \mathrm{Cl} 1^{\mathrm{i}}$ & 0.90 & 2.51 & $3.302(2)$ & 147 \\
\hline $\mathrm{N} 2-\mathrm{H} 2 A \cdots \mathrm{Cl} 2^{\mathrm{i}}$ & 0.90 & 2.85 & $3.441(2)$ & 124 \\
\hline $\mathrm{N} 2-\mathrm{H} 2 \mathrm{~B}^{\cdots} \mathrm{Cl}^{\mathrm{ii}}$ & 0.90 & 2.51 & $3.266(2)$ & 142 \\
\hline $\mathrm{N} 2-\mathrm{H} 2 B \cdots \mathrm{Cl}^{\mathrm{ii}}$ & 0.90 & 2.94 & $3.603(2)$ & 132 \\
\hline $\mathrm{C} 5-\mathrm{H} 5 \cdots \mathrm{Cl} 2$ & 0.93 & 2.85 & 3.479 (3) & 126 \\
\hline $\mathrm{C} 7-\mathrm{H} 7 A^{\cdots} \cdots \mathrm{Cl} 1$ & 0.97 & 2.83 & 3.582 (3) & 135 \\
\hline $\mathrm{C} 8-\mathrm{H} 8 B \cdots \mathrm{Cl} 2^{\mathrm{i}}$ & 0.96 & 2.89 & $3.560(3)$ & 128 \\
\hline $\mathrm{C} 5-\mathrm{H} 5 \cdots \mathrm{Cl} 3^{\mathrm{iii}}$ & 0.93 & 2.96 & 3.617 (3) & 129 \\
\hline $\mathrm{C} 8-\mathrm{H} 8 A \cdots \mathrm{N} 1^{\mathrm{iv}}$ & 0.96 & 2.90 & 3.570 (3) & 128 \\
\hline $\mathrm{C} 8-\mathrm{H} 8 \mathrm{C} \cdots \mathrm{Cl} 2^{\mathrm{iv}}$ & 0.96 & 2.85 & 3.727 (3) & 152 \\
\hline
\end{tabular}

Symmetry codes: (i) $\mathrm{x},-\mathrm{y}+1 / 2, \mathrm{z}+1 / 2$; (ii) $-\mathrm{x}+1, \mathrm{y}+1 / 2,-\mathrm{z}+1 / 2$; (iii) $-\mathrm{x}+1, \mathrm{y}-1 / 2,-\mathrm{z}+1 / 2$; (iv) $-\mathrm{x}, \mathrm{y}+1 / 2,-\mathrm{z}+1 / 2$.

\section{Conclusion}

A novel complex $\mathrm{ZnCl}_{3}$ (methyl-(2-pyridin-2-yl-ethyl)-ammonium) has been synthesized at room temperature and characterized by single crystal X-ray diffraction. In the crystal structure of the title compound, the Zn(II) ion is tetracoordinated to one nitrogen atom of the monodentate cationic ligand and to three chlorine ligands. All the components of this material are interconnected via $\mathrm{N}-\mathrm{H} \cdots \mathrm{Cl}, \mathrm{C}-\mathrm{H} \cdots \mathrm{Cl}$ and $\mathrm{C}-\mathrm{H} \cdots \mathrm{N}$ hydrogen bonds to form layers parallel to the (b, c) plan.

\section{Supplementary Data}

Crystallographic data for the structural analysis have been deposited with the Cambridge Crystallographic Data Centre, CCDC No 1035723. These data can be obtained free of charge via http://www.ccdc.cam.ac.uk/conts/retrieving.html, or from the CCDC, 12 Union Road, Cambridge, CB2 1EZ, UK: fax: (+44) 01223-336-033; e-mail: deposit@ccdc.cam.ac.

\section{Acknowledgements}

We would like to thank the Tunisian Secretariat of State for Scientific Research and Technology for its financial support. 


\section{References}

[1] Dybtsev, D.N., Chun, H., Yoon, S.H., Kim, D. and Kim, K. (2004) Microporous Manganese Formate: A Simple MetalOrganic Porous Material with High Framework Stability and Highly Selective Gas Sorption Properties. Journal of the American Chemical Society, 126, 32-33. http://dx.doi.org/10.1021/ja038678c

[2] Smith, D.W. (1976) Chlorocuprates(II). Coordination Chemistry Reviews, 21, 93-158. http://dx.doi.org/10.1016/S0010-8545(00)80445-2

[3] Ye, B.H., Chem, X.M., Xue, G.Q. and Ji, L.N. (1998) Mononuclear Nickel Complexes Assembled into Two-Dimensional Networks via Hydrogen Bonds and $\pi-\pi$ Stacking Interactions. Journal of the Chemical Society, Dalton Transactions, 17, 2827-2832. http://dx.doi.org/10.1039/a802695e

[4] Sorenson, J.R.J. (1976) Copper Chelates as Possible Active Forms of the Antiarthritic Agents. Journal of Medicinal Chemistry, 19, 135-148. http://dx.doi.org/10.1021/jm00223a024

[5] May, P.M. and Williams, D.R. (1981) Role of Low Molecular Weight Copper Complexes in the Control of Rheumatoid Arthritis. In: Metal Ions in Biological Systems, Vol. 12, Helmut Sigel, New York, 283-317.

[6] Subramanian, P.S. and Srinivas, D. (1996) Synthesis, Spectral Characterization and Magnetic Properties of DicarboxylatoBridged Dinuclear Copper(II) Complexes with n-Pyridylsalicylidenaminato Ligand. Polyhedron, 15, 985-989. http://dx.doi.org/10.1016/0277-5387(95)00307-X

[7] Kaabi, K., El Glaoui, M., Zeller, M. and Ben Nasr, C. (2010) Diaquabis(Perchlorato)(1,10-Phenanthroline)Copper(II). Acta Crystallographica, E66, m1145-m1146. http://dx.doi.org/10.1107/S160053681003312X

[8] Sheldrick, G.M. and SHELXS86 (1986) Program for Crystal Structure solution. Acta Crystallographica, A24, 351359.

[9] Betteridge, P.W., Carruthers, J.R., Cooper, R.I., Prout, K. and Watkin, D.J. (2003) CRYSTALS Version 12: Software for Guided Crystal Structure Analysis. Journal of Applied Crystallography, 36, 1487. http://dx.doi.org/10.1107/S0021889803021800

[10] Brandenburg, K. (1998) Diamond Version 2.0 Impact GbR. Bonn, Germany.

[11] Macrae, C.F., Bruno, I.J., Chisholm, J.A., Edgington, P.R., McCabe, P., Pidcock, E., Rodriguez-Monge, L., Taylor, R., van de Streek, J. and Wood, P.A. (2008) New Features for the Visualization and Investigation of Crystal Structures. Journal of Applied Crystallography, 41, 466-470. http://dx.doi.org/10.1107/S0021889807067908

[12] Chen, X.-F., Liu, S.-H., Zhu, X.-H., Vittal, J.J., Tan, E.-K. and You, X.-Z. (2000) 4,4'-Bipyridine-N: N-Bis[bis(pyrrilidinedithiocarboxylato-S,S')zinc(II). Acta Crystallographica, C56, 42-43.

[13] Hou, J.-J. and Zhang, X.-M. (2006) Structures and Magnetic Properties of a Series of Metal Phosphonoacetates Synthesized from in Situ Hydrolysis of Triethyl Phosphonoacetate. Crystal Growth \& Design, 6, 1445-1452.

[14] Smolenaers, P.J., Beattie, J.K. and Hutchinson, N.D. (1981) Crystal and Molecular Structure of Racemic Tris(Ethylenediamine)Ruthenium(II) Tetrachlorozincate(II). Inorganic Chemistry, 20, 2202-2206. http://dx.doi.org/10.1021/ic50221a052

[15] Gahan, L.R., Hambley, T.W., Sargeson, A.M. and Snow, M.R. (1982) Encapsulated Metal Ions: Synthesis, Structure, and Spectra of Nitrogen-Sulfur Ligand Atom Cages Containing Cobalt(III) and Cobalt(II). Inorganic Chemistry, 21, 2699-2706. http://dx.doi.org/10.1021/ic00137a033

[16] Chen, W.-T., Liu, D.-S., Ying, S.-M., Chen, H.-L. and Xu, Y.-P. (2008) ZnCl (4-Methyl-4,4-Bipyridinium) with 4-Methyl4,40-Bipyridinium Generated in Situ: Synthesis, Structure and Photoluminescence. Inorganic Chemistry Communications, 11, 1212-1214. http://dx.doi.org/10.1016/j.inoche.2008.07.011 
Scientific Research Publishing (SCIRP) is one of the largest Open Access journal publishers. It is currently publishing more than 200 open access, online, peer-reviewed journals covering a wide range of academic disciplines. SCIRP serves the worldwide academic communities and contributes to the progress and application of science with its publication.

Other selected journals from SCIRP are listed as below. Submit your manuscript to us via either submit@scirp.org or Online Submission Portal.
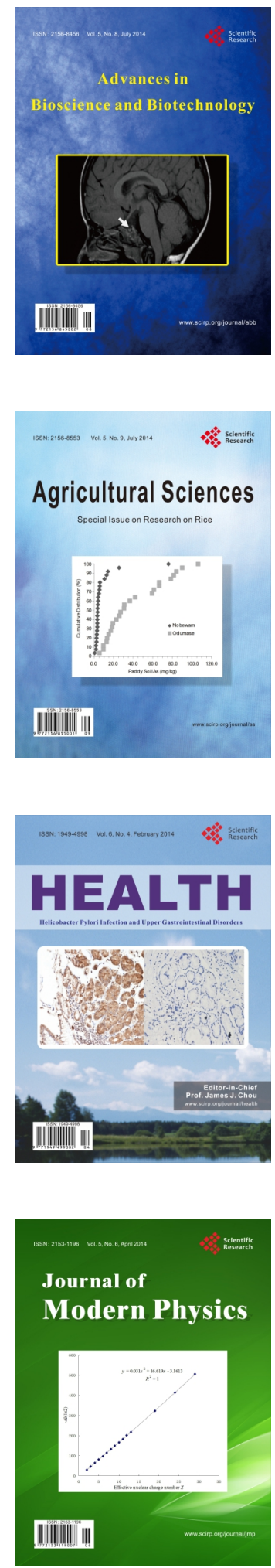
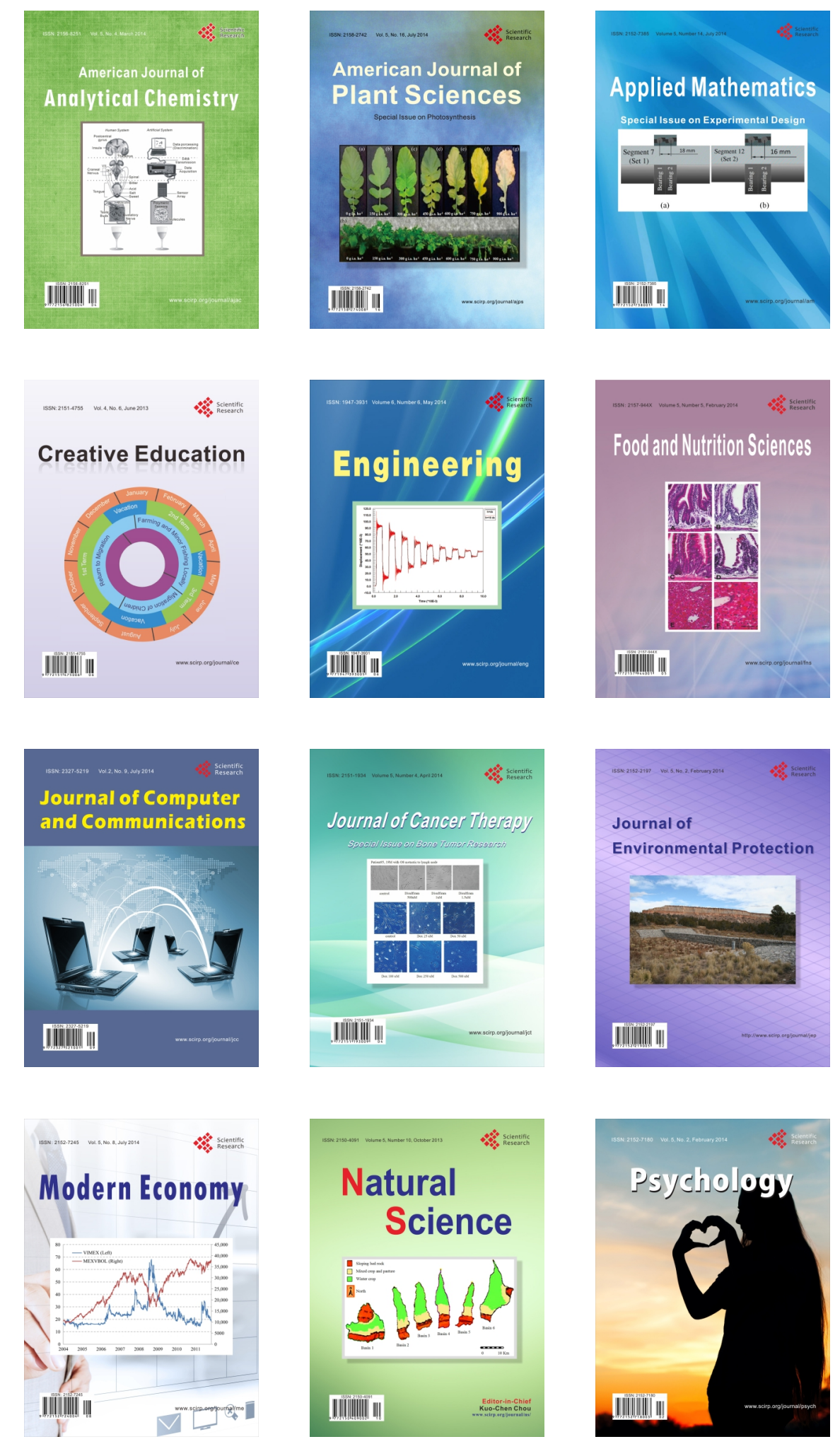